\title{
Signal Transduction Pathways Involved in Oxidative Stress-Induced Intestinal Epithelial Cell Apoptosis
}

\author{
YUNING ZHOU, QINGDING WANG, B. MARK EVERS, AND DAI H. CHUNG \\ Department of Surgery, The University of Texas Medical Branch, Galveston, Texas 77555
}

\begin{abstract}
Necrotizing enterocolitis (NEC) is a devastating inflammatory condition of the gut that occurs in premature infants. Ischemia-reperfusion gut injury with production of reactive oxygen species (ROS) is thought to contribute to NEC; the exact cellular mechanisms involved are largely unknown. The purpose of this study was to determine the intracellular signaling transduction pathways involved in oxidative stress-induced intestinal epithelial cell apoptosis. $\mathrm{H}_{2} \mathrm{O}_{2}$ treatment resulted in rat intestinal epithelial cell apoptosis in a dose- and time-dependent manner; the caspase inhibitor, zVAD-fmk, blocked this response. Western blotting was performed to determine phosphorylation of kinases and ELISA was used to assess DNA fragmentation, as a measure of apoptosis. A rapid increase in phosphorylation of extracellular signal-related kinase (ERK)1/2, c-Jun N-terminal kinase (JNK)1/2, and Akt was noted. Inhibition of ERK and JNK decreased $\mathrm{H}_{2} \mathrm{O}_{2}$-induced apoptosis. Additionally, inhibition of protein kinase $\mathrm{C}$ (PKC) and phosphatidylinositol 3-kinase (PI3-K) attenuated and enhanced $\mathrm{H}_{2} \mathrm{O}_{2}$-mediated apoptosis and mitochondrial membrane potential decrease, respectively. Furthermore, activation of PKC reduced the Akt phosphorylation,
\end{abstract}

ABSTRACT

whereas inhibition of PKC attenuated $\mathrm{H}_{2} \mathrm{O}_{2}$-mediated activation of caspase- 3 and enhanced the $\mathrm{H}_{2} \mathrm{O}_{2}$-induced Akt phosphorylation. This study shows that activation of multiple signaling transduction pathways occurs during oxidative stress-induced intestinal epithelial cell injury. In contrast to ERK, JNK, and $\mathrm{PKC}, \mathrm{PI} 3-\mathrm{K} / \mathrm{Akt}$ may play an important role as a protective cellular signaling pathway during this process. (Pediatr Res 58: 1192-1198, 2005)

\section{Abbreviations}

ERK1/2, extracellular signal-regulated kinases 1 and 2

JNK1/2, c-Jun N-terminal kinases 1 and 2

MAPK, mitogen-activated protein kinase

NEC, necrotizing enterocolitis

PARP, poly (ADP-ribose) polymerase

PI3-K, phosphatidylinositol 3-kinase

PKC, protein kinase C

PMA, phorbol-12-myristate-13-acetate

RIE-1, rat intestinal epithelial

ROS, reactive oxygen species
NEC, characterized by inflammation, ischemia, and necrosis of the intestine, is a devastating condition in premature infants (1). Recent advances in the care of premature infants born with respiratory insufficiency have resulted in increased survival for extremely small premature infants and, as a result, the incidence of NEC has steadily risen. There are numerous presumed risk factors for NEC, which include perinatal stress, hypoxia, mesenteric ischemia-reperfusion, and hyperosmolar enteral feedings (2). In particular, a potential link between ROS produced by ischemia-reperfusion injury to the gut and the development of NEC has been suggested by several studies (3-5). However, the exact cellular signaling involved in oxi-

Received December 21, 2004; accepted May 19, 2005.

Correspondence: Dai H. Chung, M.D., Department of Surgery, The University of Texas Medical Branch, 301 University Blvd., Galveston, TX 77555-0353; e-mail: dhchung@ utmb.edu

This work was supported by grants RO1 DK61470, RO1 DK48498 and PO1 DK35608 from the National Institutes of Health and grants 8560, 8800 from Shriners Burns Hospital.

DOI: 10.1203/01.pdr.0000185133.65966.4e dative stress-mediated intestinal epithelial cell apoptosis, which may occur during NEC, has not been clearly defined.

Cells undergo oxidative stress when levels of ROS exceed the counter-regulatory antioxidant capacity of the cell (6). Cellular responses to oxidative stress can vary from growth arrest to cell death depending upon the stress stimuli, duration of exposure, cell type, and surrounding cell environment (7). ROS-mediated cell damage is implicated in the pathogenesis of a variety of diseases (7). In the gastrointestinal tract, ROSinduced injury endothelial dysfunction is considered to be an important cellular mechanism in indomethacin-induced gastric mucosal injury (8) as well as in the colonic inflammation associated with ulcerative colitis (9). The exact cellular signaling involved in ROS-mediated intestinal cell injury in NEC is not well defined.

Oxidative stress is known to induce apoptosis in a variety of cell types by activating intracellular cell death signaling cascades (6). On the other hand, oxidative stress can also trigger the activation of certain signaling pathways that protect against cell death $(10,11)$. For example, treatment with hydrogen 
peroxide $\left(\mathrm{H}_{2} \mathrm{O}_{2}\right)$ to generate ROS activates members of the MAPK family (ERK1/2, JNK1/2, and p38 MAPKs) and PI3-K. It is generally accepted that ERK $1 / 2$ and PI $3-\mathrm{K}$ activation promotes cell survival by activating antiapoptotic signaling pathways, whereas activation of JNK and p38 MAPK is associated with cell death (12-14). However, recent studies have suggested an apoptotic function for mitogen-activated protein kinase kinase (MEK)/ERK in $\mathrm{H}_{2} \mathrm{O}_{2}$-mediated signals $(15,16)$. In addition, PI3-K activation, resulting in phosphorylation of its downstream effector Akt (phospho-Akt), appears to play an essential role in cell survival by preventing the oxidative stress-induced cell death (11).

Considering the pivotal role of ROS in intestinal inflammation, we determined the intracellular signaling transduction pathways involved in the $\mathrm{H}_{2} \mathrm{O}_{2}$-induced RIE-1 cell injury in the present study. We show that $\mathrm{H}_{2} \mathrm{O}_{2}$ induces apoptosis in RIE-1 cells with increased phosphorylation of ERK1/2, JNK1/2, and Akt. Inhibition of MEK/ERK1/2, JNK, and protein kinase $\mathrm{C}$ (PKC) attenuated, whereas inhibition of PI3-K enhanced $\mathrm{H}_{2} \mathrm{O}_{2}$-mediated apoptosis. Moreover, we found that inhibition of PKC results in the enhanced Akt phosphorylation and attenuates $\mathrm{H}_{2} \mathrm{O}_{2}$-induced RIE-1 cell death.

\section{MATERIALS AND METHODS}

Reagents. Wortmannin, PMA, and $\mathrm{H}_{2} \mathrm{O}_{2}$ were purchased from Sigma Chemical Co. (St. Louis, MO). GF109203x, U0126, and SP600125 were from Calbiochem (San Diego, CA). Rabbit polyclonal anti-ERK1, rabbit polyclonal anti-phospho-ERK1/2, rabbit polyclonal anti-caspase-3, and rabbit anti-PARP were purchased from Santa Cruz Biotechnology (Santa Cruz, CA). The anti-actin antibody was purchased from Sigma Chemical Co. Rabbit anti-JNK antibody, rabbit anti-phospho-JNK antibody, rabbit anti-phospho-Akt (Ser473) antibody, and rabbit anti-Akt antibody were purchased from Cell Signaling (Beverly, MA). Tissue culture media and reagents were obtained from Invitrogen (Carlsbad, CA). Polyvinylidene diflouride PVDF membranes were from Millipore Corp. (Bedford, MA). The enhanced chemiluminescence system was purchased from Amersham Biosciences (Piscataway, NJ).

Cell culture. RIE-1 cells were maintained in Dulbecco's modified Eagle medium supplemented with $10 \%$ fetal bovine serum and cultured at $37^{\circ} \mathrm{C}$ under an atmosphere containing $5 \% \mathrm{CO}_{2}$. All experiments were performed on cells within $6 \mathrm{wk}$ of culture from liquid nitrogen stocks and free of $\mathrm{Myco}$ plasma contamination. To eliminate the potential ROS scavenger action of DMSO (17) in vehicle, we used the same concentrations of DMSO $(0.1 \%)$ for both inhibitors and vehicle.

DNA fragmentation assay. Cells were plated in 96-well plates $24 \mathrm{~h}$ before treatment. DNA fragmentation was evaluated by examination of cytoplasmic histone-associated DNA fragments (mononucleosomes and oligonucleosomes) using a Cell Death Detection ELISA ${ }^{\text {Plus }}$ kit (Roche Molecular Biochemicals, Indianapolis, IN) according to the manufacturer's instructions.

Protein extraction and Western blot analysis. Cells were lysed with TNN buffer [50 mM Tris-HCI (pH 7.5), $150 \mathrm{mM} \mathrm{NaCl}, 0.5 \mathrm{mM} \mathrm{NP} 40,50 \mathrm{mM} \mathrm{NaF}$, $1 \mathrm{mM}$ sodium orthovanadate, $1 \mathrm{mM}$ DTT, $1 \mathrm{mM}$ phenylmethylsulfonyl fluoride, and $25 \mu \mathrm{g} / \mathrm{mL}$ each of aprotinin, leupeptin, and pepstatin A] at $4{ }^{\circ} \mathrm{C}$ for $30 \mathrm{~min}$. Lysates were clarified by centrifugation $(10,000 \times g$ for $30 \mathrm{~min}$ at $4^{\circ} \mathrm{C}$ ), and protein concentrations were determined using the method described by Bradford (18). Total protein $(100 \mu \mathrm{g})$ was resolved on a $10 \%$ polyacrylamide gel and transferred to polyvinylidene diflouride membranes. Filters were incubated overnight at $4^{\circ} \mathrm{C}$ in a blocking solution (Tris-buffered saline containing 5\% nonfat dried milk and $0.1 \%$ Tween 20), followed by a 1-h incubation with primary antibodies at $4{ }^{\circ} \mathrm{C}$ overnight. Filters were washed three times in a blocking solution and incubated with horseradish peroxidaseconjugated second antibodies for $1 \mathrm{~h}$ at room temperature. After three additional washes, the immune complexes were visualized by enhanced chemiluminescence system.

JC-1 mitochondrial membrane potential detection. The mitochondrial membrane potential was analyzed using MitoProbe JC-1 Assay kit (Molecular Probes, Eugene, OR). The collapse in the electrochemical gradient across the mitochondrial membrane was measured using a fluorescent cationic dye 5,5',6,6,-tetrachloro-1,1',3,3'-tetraethyl-benzamidazolo-carbocyanin iodide, known as JC-1. This dye exhibits potential dependent accumulation in mitochondrial matrix (19). Cells $\left(1 \times 10^{6}\right)$ were incubated with $2 \mu \mathrm{M} \mathrm{JC}-1$ for 15 min at room temperature in darkness. Cells were washed twice with PBS at $4^{\circ} \mathrm{C}$, resuspended in $0.5 \mathrm{~mL} \mathrm{PBS}$, and analyzed on a FACSCalibur flow cytometer.

Statistical analysis. Results are expressed as the mean \pm SEM. The data in the figures were analyzed using the Kruskal-Wallis test and assessed at the 0.05 level of significance.

\section{RESULTS}

$\mathrm{H}_{2} \mathrm{O}_{2}$ induces apoptosis in RIE-1 cells. $\mathrm{H}_{2} \mathrm{O}_{2}$ treatment resulted in RIE-1 cell death in a dose-dependent manner with a significant induction of cell death at concentrations of 100 $500 \mu \mathrm{M}$ (Fig. $1 A$ ). The mechanism of apoptosis is mediated by sequential activation of caspases (20). To confirm whether $\mathrm{H}_{2} \mathrm{O}_{2}$ is inducing apoptosis in RIE-1 cells through caspase activation, we next pretreated cells with the pan-caspase inhibitor, zVAD-fmk (20), before $\mathrm{H}_{2} \mathrm{O}_{2}$ treatment. Pretreatment with zVAD-fmk effectively inhibited apoptosis induced by $\mathrm{H}_{2} \mathrm{O}_{2}$ in a dose-dependent manner, suggesting a role for caspase activation in $\mathrm{H}_{2} \mathrm{O}_{2}$-mediated induction of apoptosis (Fig. 1B).

To further confirm the activation of caspase pathway in the apoptotic effect of $\mathrm{H}_{2} \mathrm{O}_{2}$ on RIE-1 cells, we next determined protein expression of cleavage products of caspase- 3 and PARP after treatment with $\mathrm{H}_{2} \mathrm{O}_{2}$. Treatment with $\mathrm{H}_{2} \mathrm{O}_{2}$ resulted in activation of caspase- 3 , as demonstrated by cleavage of pro-caspase- 3 noted by increased expression of the $M_{\mathrm{r}}$ 17,000 cleavage product (i.e. active caspase-3). In addition, cleavage of PARP $\left(M_{\mathrm{r}} 85,000\right.$ cleavage product) was also noted (Fig. 1C).

$\mathrm{H}_{2} \mathrm{O}_{2}$ activates ERK1/2, JNK, and Akt. We found that RIE-1 cells undergo apoptosis when exposed to $\mathrm{H}_{2} \mathrm{O}_{2}$ in a dose- and time-dependent manner. Oxidative stress is known to activate multiple signal transduction pathways in many experimental systems $(6,7)$. To identify the signaling mechanisms activated by $\mathrm{H}_{2} \mathrm{O}_{2}$ in RIE- 1 cells, we assessed the phosphorylated protein expression of ERK, JNK, and Akt. Treatment with $\mathrm{H}_{2} \mathrm{O}_{2}$ resulted in marked increases in phosphorylation of ERK1/2 and JNK1/2, without affecting the total protein expression levels (Fig. 2). The activation of ERK1/2 and JNK1/2 occurred at $25 \mathrm{~min}$ after the addition of $\mathrm{H}_{2} \mathrm{O}_{2}(500 \mu \mathrm{M})$, peaked at 30-60 min, and returned to basal level by $2 \mathrm{~h}$. Interestingly, $\mathrm{H}_{2} \mathrm{O}_{2}$ treatment resulted in sustained activation of Akt throughout the time course.

Effects of protein kinase inhibition on $\mathrm{H}_{2} \mathrm{O}_{2}$-mediated apoptosis. To further delineate the signaling pathways involved in $\mathrm{H}_{2} \mathrm{O}_{2}$-mediated apoptosis, RIE-1 cells were pretreated for 30 min with inhibitors to JNK (SP600125), ERK1/2 upstream kinase MEK1 (U0126), or combination of both for $30 \mathrm{~min}$ before treatment with $\mathrm{H}_{2} \mathrm{O}_{2}(500 \mu \mathrm{M})$. Cell death was assayed at $3 \mathrm{~h}$ after addition of $\mathrm{H}_{2} \mathrm{O}_{2}$. As expected, $\mathrm{H}_{2} \mathrm{O}_{2}$ induced RIE-1 cell death; this induction was partially attenuated by treatment with either SP600125 or U0126 (Fig. 3A). However, combination treatment did not show synergistic inhibition of cell death. We also confirmed the inhibitory effect of U0126 on the MEK/ERK1/2 pathway by determining phosphorylated protein level of ERK1/2 by Western blot. As noted previously, phospho-ERK1/2 was increased in $\mathrm{H}_{2} \mathrm{O}_{2}$-treated RIE-1 cells, 
A

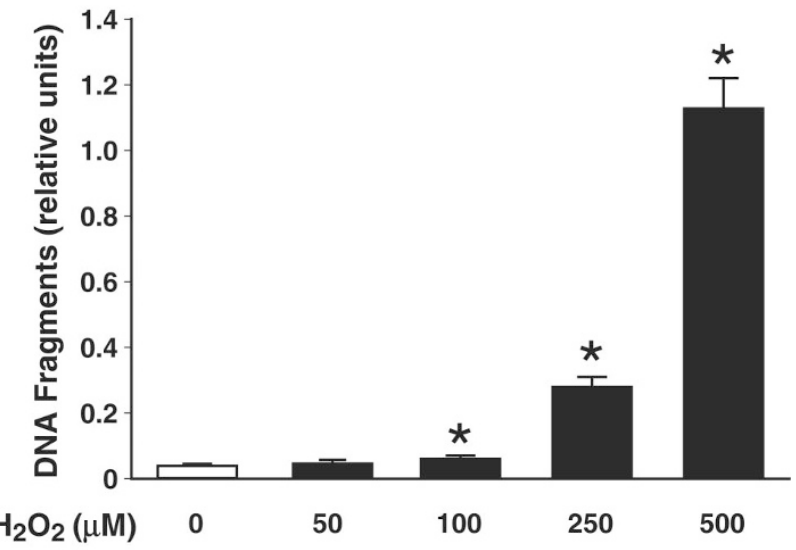

B

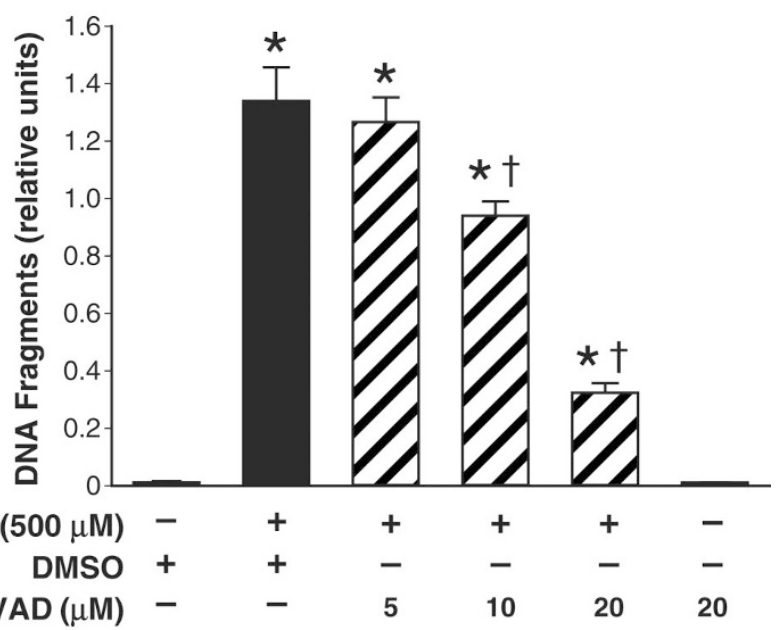

C

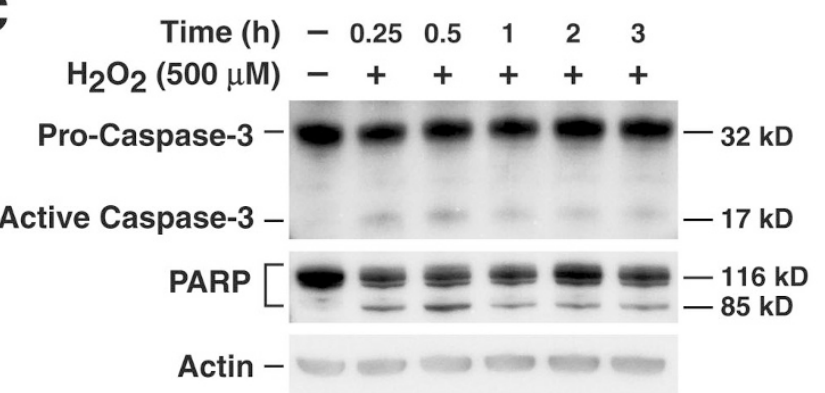

Figure 1. $\mathrm{H}_{2} \mathrm{O}_{2}$ induces RIE-1 cell apoptosis. (A) RIE-1 cells were plated for $24 \mathrm{~h}$ before treatment with $\mathrm{H}_{2} \mathrm{O}_{2}$ for $3 \mathrm{~h}$ or $(B)$ pretreated with zVAD-fmk for $30 \mathrm{~min}$ before treatment with $\mathrm{H}_{2} \mathrm{O}_{2}$. Apoptosis was estimated by a DNA fragmentation ELISA (data represent triplicate determinations $\pm \mathrm{SEM} ; * p<$ $0.05 v s$ control; $\uparrow p<0.05$ vs $\mathrm{H}_{2} \mathrm{O}_{2}$ alone). Experiments were repeated twice. (C) RIE-1 cells were treated with $\mathrm{H}_{2} \mathrm{O}_{2}$ for various time points. A representative Western blot from three separate experiments is shown here.

and this response was completely blocked by U0126 compound (Fig. 3B).

To delineate the role of PI3-K/Akt and PKC signaling pathways involved in $\mathrm{H}_{2} \mathrm{O}_{2}$-mediated apoptosis, RIE-1 cells were pretreated for 30 min with Akt upstream kinase PI3-K inhibitor, wortmannin or PKC inhibitor GF109203x, before addition of $\mathrm{H}_{2} \mathrm{O}_{2}(500 \mu \mathrm{M})$. Wortmannin significantly enhanced $\mathrm{H}_{2} \mathrm{O}_{2}$-mediated RIE-1 cell death at $3 \mathrm{~h}$ (Fig. $3 \mathrm{C}$ ). In contrast, GF109203x markedly attenuated $\mathrm{H}_{2} \mathrm{O}_{2}$-induced RIE-1 cell death. The inhibitory effect of wortmannin on the PI3-K/Akt pathway was also confirmed by demonstrating the

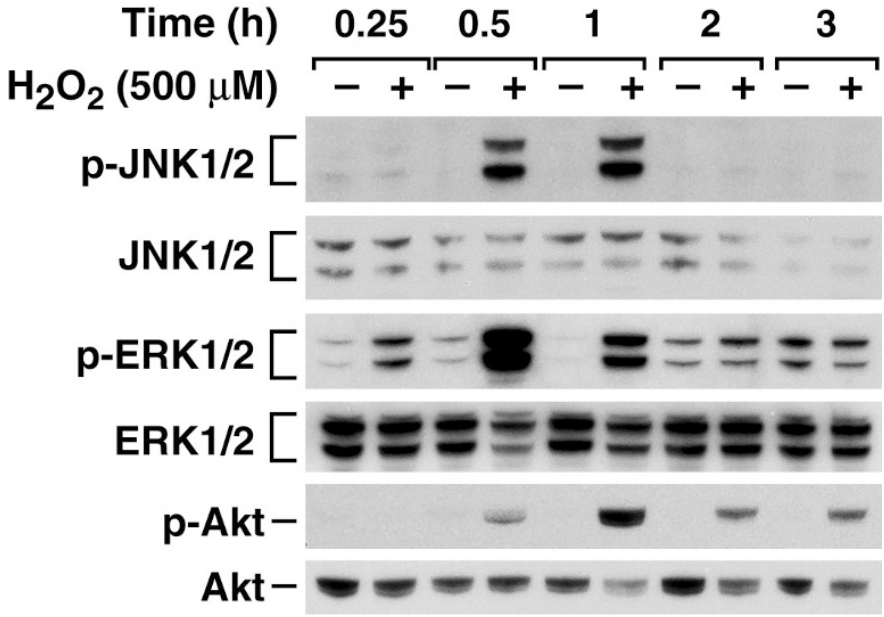

Figure 2. Activation of signal transduction pathways by $\mathrm{H}_{2} \mathrm{O}_{2}$. RIE-1 cells were treated with $\mathrm{H}_{2} \mathrm{O}_{2}$ over a time course for Western blot analysis. A representative blot from three separate experiments is shown here.

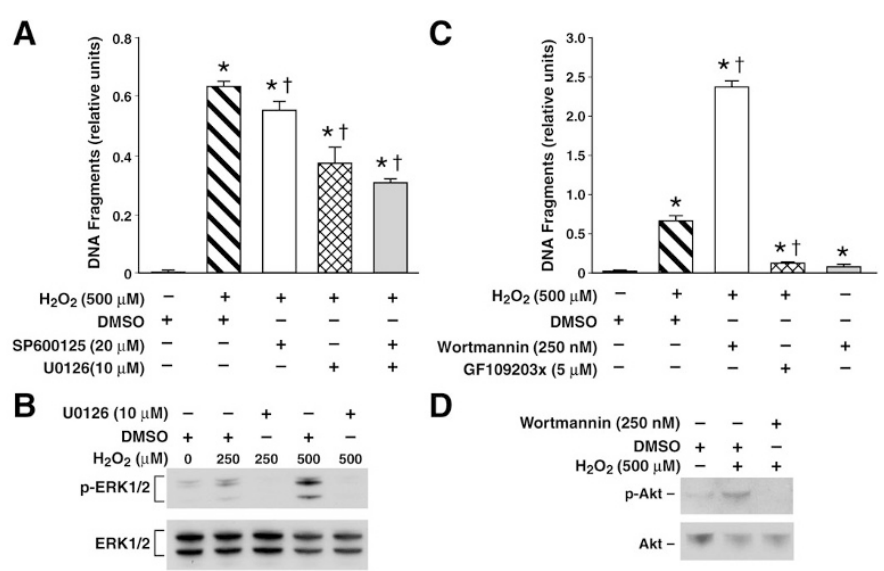

Figure 3. Effects of kinase inhibitors on $\mathrm{H}_{2} \mathrm{O}_{2}$-induced RIE-1 cell death. (A, $C)$ RIE-1 cells were pretreated with kinase inhibitors [JNK inhibitor SP600125, the MEK1 inhibitor U0126 or combination (A) and PI3-K inhibitor wortmannin or PKC inhibitor GF109203x (C)] for $30 \mathrm{~min}$ before treatment with $\mathrm{H}_{2} \mathrm{O}_{2}$ for $3 \mathrm{~h}$. Apoptosis was estimated by a DNA fragmentation ELISA (data represent triplicate determinations $\pm \mathrm{SEM} ; * p<0.05$ vs control; $\uparrow p<$ 0.05 vs $\mathrm{H}_{2} \mathrm{O}_{2}$ alone). Experiments were repeated twice. (B) RIE-1 cells were pretreated with the U0126 for 30 min before treatment with $\mathrm{H}_{2} \mathrm{O}_{2}$ for $30 \mathrm{~min}$ and Western blotting performed. $(D)$ RIE-1 cells were pretreated with the wortmannin for 30 min before treatment with $\mathrm{H}_{2} \mathrm{O}_{2}$ for $3 \mathrm{~h}$ and Western blotting performed. Representative blots from three separate experiments are shown as $(B)$ and $(D)$.

inhibition of $\mathrm{H}_{2} \mathrm{O}_{2}$-induced Akt phosphorylation by wortman$\operatorname{nin}$ in Figure $3 D$. Collectively, these results suggest a proapoptotic role for the MEK/ERK, JNK, and PKC pathways and an antiapoptotic role for PI3-K/Akt pathway in $\mathrm{H}_{2} \mathrm{O}_{2}$-induced RIE-1 cell death.

PKC negatively regulates Akt activity in RIE-1 cells. To further determine the molecular mechanisms involved in the effects of $\mathrm{PKC}$ or $\mathrm{PI} 3-\mathrm{K}$ inhibition on $\mathrm{H}_{2} \mathrm{O}_{2}$-induced apoptosis, we next determined activation of caspase-3. As expected, treatment with $\mathrm{H}_{2} \mathrm{O}_{2}$ resulted in activation of caspase-3; this activation was attenuated by treatment with GF109203x (an inhibitor of PKC) as demonstrated by decreased cleavage of pro-caspase-3 (Fig. 4A). In contrast, pretreatment with wortmannin significantly enhanced cleavage of pro-caspase-3. 


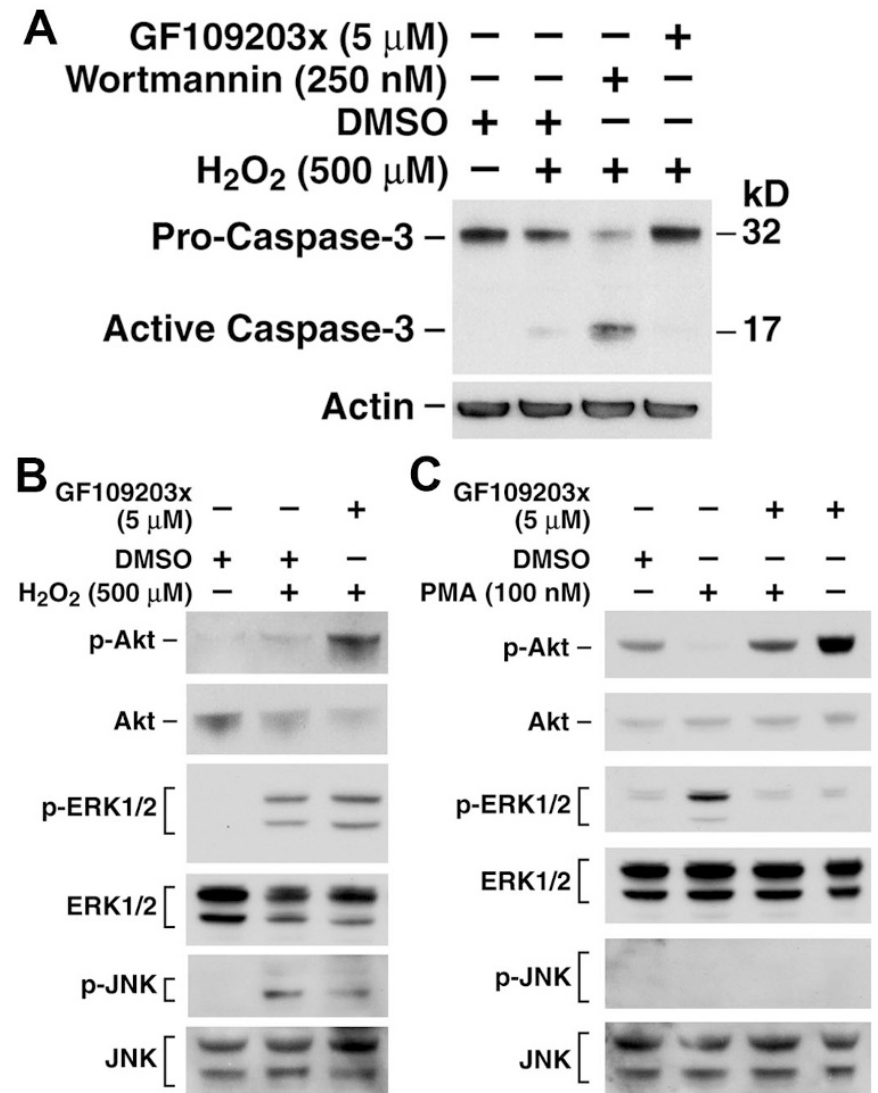

Figure 4. Inhibition of PKC results in the activation of Akt and blocks $\mathrm{H}_{2} \mathrm{O}_{2}$-induced caspase- 3 cleavage. (A) RIE- 1 cells were pretreated with the PI3-K inhibitor wortmannin or the PKC inhibitor GF109203x for $30 \mathrm{~min}$ before treatment with $\mathrm{H}_{2} \mathrm{O}_{2}$ for $3 \mathrm{~h}$ for Western blot analysis. $(B, C)$ RIE-1 cells were pretreated with the GF109203x for 30 min before treatment with $\mathrm{H}_{2} \mathrm{O}_{2}(B)$ or PMA $(C)$ for Western blot analysis. Representative blots from three separate experiments are shown here.

Because PI3-K/Akt appears to be an important antiapoptotic pathway during $\mathrm{H}_{2} \mathrm{O}_{2}$-induced RIE-1 cell death and inhibition of PKC significantly prevents $\mathrm{H}_{2} \mathrm{O}_{2}$-induced cell death, we next determined the regulation of Akt phosphorylation by PKC. As shown previously, treatment with $\mathrm{H}_{2} \mathrm{O}_{2}$ induced Akt phosphorylation (Fig. $4 B$ ). Interestingly, the treatment with GF109203x resulted in synergistic increase in $\mathrm{H}_{2} \mathrm{O}_{2}-$ induced activation of Akt, suggesting that significant attenuation of $\mathrm{H}_{2} \mathrm{O}_{2}$-mediated apoptosis with PKC inhibition may act through the enhanced PI3-K/Akt activation. Pretreatment with GF109203 $\times$ has no effect on $\mathrm{H}_{2} \mathrm{O}_{2}$-induced ERK1/2 or JNK phosphorylation, suggesting that $\mathrm{H}_{2} \mathrm{O}_{2}$ induces ERK1/2 or JNK phosphorylation in a PKC-independent fashion. To further delineate the regulation of Akt phosphorylation by PKC, RIE-1 cells were pretreated with the PKC inhibitor GF109203x $(5 \mu \mathrm{M})$ for 30 min before treatment with PKC activator, PMA $(100 \mathrm{nM})$ for additional $30 \mathrm{~min}$. As shown in Figure 4C, PMA reduced Akt phosphorylation. GF109203x alone increased Akt phosphorylation and attenuated PMA-reduced Akt phosphorylation. Treatment with PMA induced ERK1/2 but not JNK phosphorylation and this induction was blocked by the combination treatment with GF109203x, suggesting that PKC isoform(s) involved in PMA-induced ERK phosphorylation is different from that involved in $\mathrm{H}_{2} \mathrm{O}_{2}$-induced cell death.
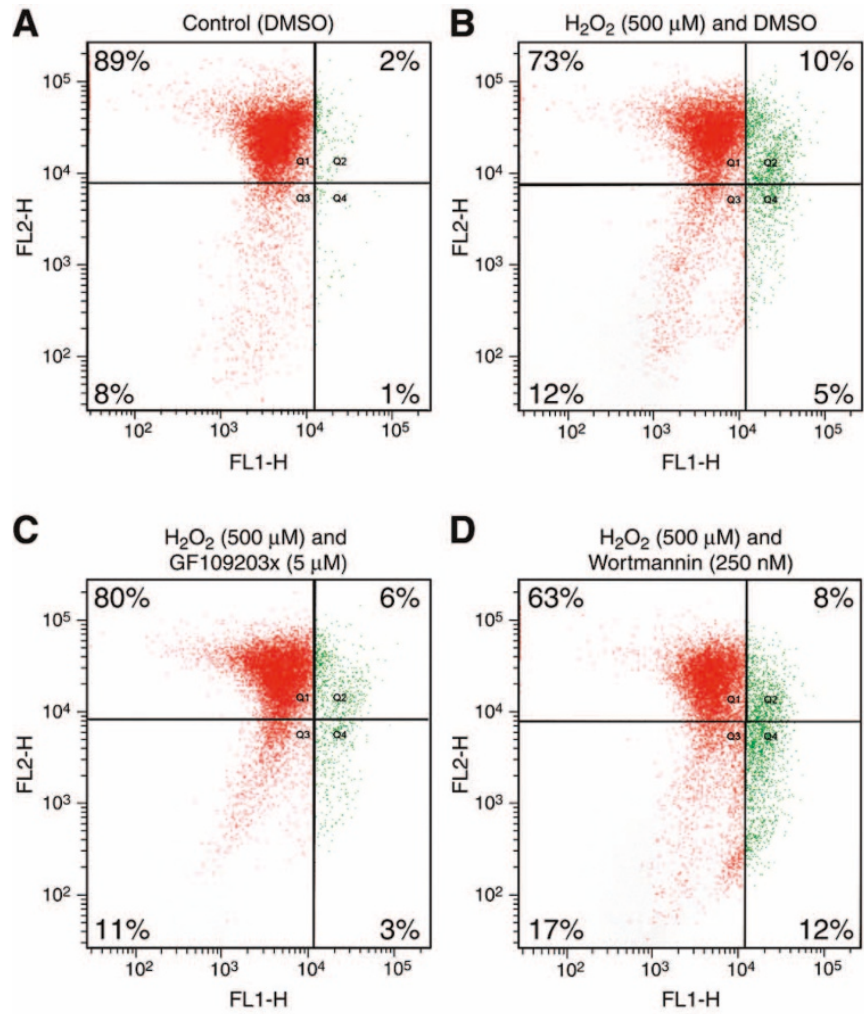

Figure 5. Inhibition of $\mathrm{PKC}$ attenuates, whereas inhibition of PI3-K enhances, $\mathrm{H}_{2} \mathrm{O}_{2}$-induced mitochondrial depolarization. RIE-1 cells were pretreated with the PI3-K inhibitor wortmannin or the PKC inhibitor GF109203x for 30 min before treatment with $\mathrm{H}_{2} \mathrm{O}_{2}$ for $3 \mathrm{~h}$. Cells were labeled with $2 \mu \mathrm{M}$ JC-1 for $15 \mathrm{~min}$ at room temperature, and intensities of FL-1 and FL-2 fluorescence were measured. JC-1 fluorescence in the FL-1 channel increases as the mitochondrial membrane potential drops while its fluorescence in FL-2 channel decreases. Percentage numbers in Q1 and Q2, Q4 indicate proportion of cells with normal and depolarized mitochondria, respectively. Representative data from three separate experiments are shown here.

Inhibition of PKC attenuates, whereas inhibition of PI3-K enhances, $\mathrm{H}_{2} \mathrm{O}_{2}$-induced mitochondrial depolarization. Mitochondrial membrane depolarization, which increases permeability and releases pro-apoptotic factors into the cytosol, is an early event of apoptosis. Recently, decreased mitochondrial membrane potential was found to be the early signs of apoptosis in human intestinal epithelial cell line SW-480 (21). To determine whether the mitochondria-initiated pathway is involved in $\mathrm{H}_{2} \mathrm{O}_{2}$-induced apoptosis, we measured $\mathrm{H}_{2} \mathrm{O}_{2}$ induced alterations in mitochondrial membrane potential and the effect of PKC or PI3-K inhibition. In healthy cells, lipophilic cation JC-1 exists as a monomer in the cytosol (FL-1 positive; green) and also accumulates as aggregates in the mitochondria (FL-2 positive; red). In apoptotic and necrotic cells, JC-1 exists exclusively in monomer form and produces a green cytosolic signal (22). As shown in Figure 5, treatment with $\mathrm{H}_{2} \mathrm{O}_{2}$ resulted in a decline in the mitochondrial membrane potential (Fig. 5, $A$ and $B$ ), implicating altered mitochondrial membrane permeability as an important event for $\mathrm{H}_{2} \mathrm{O}_{2}$ induced apoptosis in RIE-1 cells. Pretreatment with PKC inhibitor GF109203x attenuated $\mathrm{H}_{2} \mathrm{O}_{2}$-induced mitochondrial depolarization (Fig. 5C). In contrast, pretreatment with wortmannin significantly enhanced $\mathrm{H}_{2} \mathrm{O}_{2}$-induced mitochondrial 
depolarization (Fig. 5D). These results suggest that regulation of $\mathrm{H}_{2} \mathrm{O}_{2}$-induced apoptosis by PKC or PI3-K may lie upstream of mitochondria.

\section{DISCUSSION}

In this study, we found that $\mathrm{H}_{2} \mathrm{O}_{2}$ treatment induces the phosphorylation of ERK, JNK, and Akt, resulting in RIE-1 cell apoptosis via the caspase pathway. The activation of ERK and JNK may be involved in the $\mathrm{H}_{2} \mathrm{O}_{2}$-induced intestinal epithelial cell apoptosis since the inhibition of either pathway resulted in attenuation of apoptotic response. In contrast, the activation of Akt may be important as the cell survival signal given the fact that inhibition of $\mathrm{PI} 3-\mathrm{K}$ significantly enhanced $\mathrm{H}_{2} \mathrm{O}_{2}$-induced cell death. Moreover, inhibition of PKC, which resulted in activation of Akt, was found to attenuate the apoptosis induced by $\mathrm{H}_{2} \mathrm{O}_{2}$.

NEC is the most common gastrointestinal tract surgical emergency in neonates. Despite recent advances, the overall mortality rate remains high, especially in extremely small premature infants. The numerous risk factors for the pathogenesis of NEC have been well described; however, the exact cellular mechanisms involved in intestinal epithelial cell injury during NEC are still not clearly elucidated. Transient mesenteric ischemia-reperfusion injury resulting in the production of ROS has been implicated to contribute to NEC (3-5). Additionally, extensive apoptosis occurs in enterocytes in the apical villi of infants with NEC (23); however, the exact role of ROS on the intestinal epithelial cell fate during NEC as well as the cellular mechanisms that are involved in this process are largely unknown. Therefore, in the present study, we attempted to investigate the role of intracellular signal transduction pathways involved in oxidative stress-induced intestinal epithelial cell apoptosis.

Oxidative stress can trigger the activation of multiple signaling pathways that influence the cytotoxicity observed in affected cells, including the activation of the MAPK cascade. The MAPK signaling, which is stimulated by growth factor receptors, is also linked to the protection of various cell types against apoptosis. Having established that $\mathrm{H}_{2} \mathrm{O}_{2}$ triggers ERK1/2, JNK1/2, and PI3-K activation in RIE-1 cells, we then investigated role of these protein kinase pathways in $\mathrm{H}_{2} \mathrm{O}_{2}$ induced cell death using a range of pharmacological inhibitors. Our results show that pretreatment with the selective MEK1 inhibitor U0126 $(10 \mu \mathrm{M})$ or JNK inhibitor SP600125 $(20 \mu \mathrm{M})$ partially reduced $\mathrm{H}_{2} \mathrm{O}_{2}$-induced apoptosis in RIE-1 cells. Similar results were found with the use of PD98059 compound, another MEK inhibitor (data not shown). These data clearly suggest that an inhibition of ERK1/2 and JNK pathways protect RIE-1 cells from $\mathrm{H}_{2} \mathrm{O}_{2}$-induced cell death.

Our results are consistent with the findings from other cell-type studies. For example, ERK1/2 is involved in neuronal cell death triggered by oxidative stress (24), and inhibition of the JNK pathway improves cell viability in response to oxidant injury (25). Furthermore, inhibition of MEK PD98059 attenuates $\mathrm{H}_{2} \mathrm{O}_{2}$-induced cell death of the human colon cancer cell line HT-29 through inhibition of JNK (16). However, several studies have also shown the opposite role of ERK1/2 pathway during oxidative stress-induced cell injury. Treatment of primary cortical neurons with the MEK1/2 inhibitors, U0126 and PD98059, have been shown to significantly increase neuronal cell loss induced by $\mathrm{H}_{2} \mathrm{O}_{2}$ and hypoxia, respectively (14). Therefore, the role of ERK1/2 in determining the fate of cells (survival or death) after oxidative stress injury is cell-type specific. Moreover, several reports have also demonstrated that $\mathrm{H}_{2} \mathrm{O}_{2}$-induced activation of ERK is mediated by both PKCdependent and -independent mechanisms $(26,27)$. In our study, treatment with PKC inhibitor, GF109203x, which attenuated $\mathrm{H}_{2} \mathrm{O}_{2}$-induced RIE-1 cell death, blocked PMA- but not $\mathrm{H}_{2} \mathrm{O}_{2}$ mediated ERK1/2 phosphorylation, suggesting that $\mathrm{H}_{2} \mathrm{O}_{2}$ may activate ERK1/2 via $\mathrm{PKC}$-independent pathway in RIE-1 cells.

Apoptotic signals by $\mathrm{H}_{2} \mathrm{O}_{2}$ also up-regulated antiapoptotic signaling, such as the PI3-K/Akt pathway. PI3-K/Akt pathway plays a critical role in human intestinal epithelial cell survival and differentiation $(28,29)$. Furthermore, the role of the PI3K/Akt pathway in protecting against ROS-induced cell death has been extensively documented $(6,11,30)$. In this study, we show that $\mathrm{H}_{2} \mathrm{O}_{2}$ stimulates Akt phosphorylation in RIE-1 cells via a PI3-K-dependent pathway suggesting that $\mathrm{H}_{2} \mathrm{O}_{2}$-induced Akt activation may be involved in protecting RIE-1 cells against oxidative stress-induced cell death. To investigate this possibility, we used the PI3-K inhibitor, wortmannin, and found that it significantly increases cell death triggered by $\mathrm{H}_{2} \mathrm{O}_{2}$. Our findings suggest that the ultimate fate of intestinal epithelial cells in response to oxidative stress-induced injury is determined by the balance between activation of apoptotic and antiapoptotic signals.

The ERK and JNK inhibition did not completely block $\mathrm{H}_{2} \mathrm{O}_{2}$-induced cell death, suggesting the involvement of multiple pathways in $\mathrm{H}_{2} \mathrm{O}_{2}$-induced apoptosis in RIE-1 cells. Indeed, our results show that inhibition of PKC using GF109203x maximally attenuated $\mathrm{H}_{2} \mathrm{O}_{2}$-induced apoptosis, indicating that $\mathrm{H}_{2} \mathrm{O}_{2}$-mediated RIE-1 cell death also requires $\mathrm{PKC}$ activation. The involvement of various isoforms of PKC in the regulation of $\mathrm{H}_{2} \mathrm{O}_{2}$-mediated processes has been documented in a number of cell types $(31,32)$; however, its role in the regulation of $\mathrm{H}_{2} \mathrm{O}_{2}$-induced intestinal epithelial cell death is undefined. The activation of selective PKC isoforms, $\delta$ and $\epsilon$, have been implicated in tumor necrosis factor (TNF)- $\alpha$ induced intestinal epithelial cell death as proapoptotic signals (33). Further studies are required to determine the role of PKC isoforms that are involved in $\mathrm{H}_{2} \mathrm{O}_{2}$-induced intestinal epithelial cell death.

Another important finding identified in our study is that PKC may play a role in $\mathrm{H}_{2} \mathrm{O}_{2}$-mediated apoptosis through the regulation of PI3-K/Akt, a critical pathway in cell survival. Our results indicated that the $\mathrm{H}_{2} \mathrm{O}_{2}$-induced apoptosis required PKC activation. Moreover, we show that inhibition of PKC contributed to the activation of Akt and in contrast, activation of PKC by PMA reduced Akt activity (Fig. $4, B$ and $C$ ). Consistent with our findings, recent studies have shown that nonselective PKC inhibitors stimulate and PMA attenuates Akt phosphorylation in A549 and HEK293 cells (34) and PKC negatively modulates the hepatocyte growth factor-induced migration, integrin expression, and PI3-K activation in human hepatoma cells (35). 
Lastly, intracellular signaling pathways directly and indirectly regulate mitochondrial membrane stability and function to ultimately dictate apoptotic fate of a cell. Activation of PKC in some cell types initiates an apoptotic pathway that involves alteration of mitochondrial membrane potential (36). Moreover, the major mechanism involved in the antiapoptotic effect of PI3-K/Akt is the phosphorylation of BAD, which is then sequestered in the cytosol and prevented from interacting with $\mathrm{Bcl}-2 / \mathrm{Bcl}-\mathrm{x}_{\mathrm{L}}$ and from disrupting the mitochondrial membrane (37). Inhibition of PI3-K/Akt signaling potentiates cytochrome $c$ release from mitochondria and induces mitochondrial transmembrane potential decrease in bovine carotid artery endothelial cells (38). In agreement with these mechanisms, we observed that activation of PKC decreases Akt phosphorylation whereas inhibition of PKC increases Akt phosphorylation and attenuates $\mathrm{H}_{2} \mathrm{O}_{2}$-induced apoptosis and mitochondrial depolarization. In contrast, inhibition of PI3-K/Akt signaling significantly potentiated $\mathrm{H}_{2} \mathrm{O}_{2}$-induced apoptosis and induced significant mitochondrial membrane potential decrease. Our results suggest that the regulation of $\mathrm{H}_{2} \mathrm{O}_{2}$-induced apoptosis by PKC may act through down-regulation of PI3-K/Akt and this regulation may occur upstream of mitochondria.

In conclusion, our study demonstrates that $\mathrm{H}_{2} \mathrm{O}_{2}$-induced apoptosis involves the activation of ERK, JNK, and PKC signaling pathways in intestinal epithelial cells, and that inhibition of PI3-K enhances apoptosis. Moreover, PKC may play an important role in $\mathrm{H}_{2} \mathrm{O}_{2}$-induced intestinal epithelial cell death through negative regulation of PI3-K/Akt and this may occur upstream of mitochondria. Further studies will be directed toward identifying the isoform(s) of PKC and the downstream mediators responsible for intestinal cell death. A better understanding of the signal transduction pathways involved in $\mathrm{H}_{2} \mathrm{O}_{2}$-induced intestinal cell death will potentially allow us to develop novel therapy in the treatment of oxidative stressmediated gut injury.

Acknowledgments. The authors thank Karen Martin for manuscript preparation and Tatsuo Uchida for assistance with statistical analysis.

\section{REFERENCES}

1. Henry MC, Moss RL 2004 Current issues in the management of necrotizing enterocolitis. Semin Perinatol 28:221-233

2. Noerr B 2003 Current controversies in the understanding of necrotizing enterocolitis. Part 1. Adv Neonatal Care 3:107-120

3. Kelly N, Friend K, Boyle P, Zhang XR,Wong C, Hackam DJ, Zamora R, Ford HR, Upperman JS 2004 The role of the glutathione antioxidant system in gut barrier failure in a rodent model of experimental necrotizing enterocolitis. Surgery 136:557566

4. Okur H, Kucukaydin M, Kose K, Kontas O, Dogam P, Kazez A 1995 Hypoxiainduced necrotizing enterocolitis in the immature rat: the role of lipid peroxidation and management by vitamin E. J Pediatr Surg 30:1416-1419

5. Clark DA, Fornabaio DM, McNeill H, Mullane KM, Caravella SJ, Miller MJ 1988 Contribution of oxygen-derived free radicals to experimental necrotizing enterocolitis. Am J Pathol 130:537-542

6. Martindale JL, Holbrook NJ 2002 Cellular response to oxidative stress: signaling for suicide and survival. J Cell Physiol 192:1-15

7. Finkel T, Holbrook NJ 2000 Oxidants, oxidative stress and the biology of ageing. Nature 408:239-247

8. Yoshikawa T, Naito Y, Kishi A, Tomii T, Kaneko T, Iinuma S, Ichikawa H, Yasuda M, Takahashi S, Kondo M 1993 Role of active oxygen, lipid peroxidation, and antioxidants in the pathogenesis of gastric mucosal injury induced by indomethacin in rats. Gut 34:732-737

9. Sedghi S, Fields JZ, Klamut M, Urban G, Durkin M, Winship D, Fretland D, Olyaee M, Keshavarzian A 1993 Increased production of luminol enhanced chemilumines- cence by the inflamed colonic mucosa in patients with ulcerative colitis. Gut 34:1191-1197

10. Wang X, Martindale JL, Liu Y, Holbrook NJ 1998 The cellular response to oxidative stress: influences of mitogen-activated protein kinase signalling pathways on cell survival. Biochem J 333(Pt 2):291-300

11. Qin S, Chock PB 2003 Implication of phosphatidylinositol 3-kinase membrane recruitment in hydrogen peroxide-induced activation of PI3K and Akt. Biochemistry 42:2995-3003

12. Xia Z, Dickens M, Raingeaud J, Davis RJ, Greenberg ME 1995 Opposing effects of ERK and JNK-p38 MAP kinases on apoptosis. Science 270:1326-1331

13. Harper SJ, LoGrasso P 2001 Signalling for survival and death in neurones: the role of stress-activated kinases, JNK and p38. Cell Signal 13:299-310

14. Crossthwaite AJ, Hasan S, Williams RJ 2002 Hydrogen peroxide-mediated phosphorylation of ERK1/2, Akt/PKB and JNK in cortical neurones: dependence on $\mathrm{Ca}(2+)$ and PI3-kinase. J Neurochem 80:24-35

15. Bhat NR, Zhang P 1999 Hydrogen peroxide activation of multiple mitogen-activated protein kinases in an oligodendrocyte cell line: role of extracellular signal-regulated kinase in hydrogen peroxide-induced cell death. J Neurochem 72:112-119

16. Salh BS, Martens J,Hundal RS, Yoganathan N, Charest D, Mui A, Gomez-Munoz A 2000 PD98059 attenuates hydrogen peroxide-induced cell death through inhibition of Jun N-Terminal Kinase in HT29 cells. Mol Cell Biol Res Commun 4:158-165

17. Zegura B, Lah TT, Filipic M 2004 The role of reactive oxygen species in microcystinLR-induced DNA damage. Toxicology 200:59-68

18. Bradford MM 1976 A rapid and sensitive method for the quantitation of microgram quantities of protein utilizing the principle of protein-dye binding. Anal Biochem $72: 248-254$

19. Smiley ST, Reers M, Mottola-Hartshorn Lin M, Chen A, Smith TW, Steele GD Jr, Chen LB 1991 Intracellular heterogeneity in mitochondrial membrane potentials revealed by a J-aggregate-forming lipophilic cation JC-1. Proc Natl Acad Sci U S A 88:3671-3675

20. Kluck RM, Bossy-Wetzel E, Green DR, Newmeyer DD 1997 The release of cytochrome c from mitochondria: a primary site for Bcl-2 regulation of apoptosis. Science 275:1132-1136

21. Li JM, Zhou H, Cai Q, Xiao GX 2003 Role of mitochondrial dysfunction in hydrogen peroxide-induced apoptosis of intestinal epithelial cells. World J Gastroenterol 9:562-567

22. Nihal M, Ahmad N, Mukhtar H, Wood GS 2005 Anti-proliferative and proapoptotic effects of (-)-epigallocatechin-3-gallate on human melanoma: possible implications for the chemoprevention of melanoma. Int J Cancer 114:513-521

23. Ford H, Watkins S, Reblock K, Rowe M 1997 The role of inflammatory cytokines and nitric oxide in the pathogenesis of necrotizing enterocolitis. J Pediatr Surg 32:275-282

24. Stanciu M, DeFranco DB 2002 Prolonged nuclear retention of activated extracellular signal-regulated protein kinase promotes cell death generated by oxidative toxicity or proteasome inhibition in a neuronal cell line. J Biol Chem 277:4010-4017

25. Li Y, Arita Y, Koo HC, Davis JM, Kazzaz JA 2003 Inhibition of c-Jun N-terminal kinase pathway improves cell viability in response to oxidant injury. Am J Respir Cell Mol Biol 29:779-783

26. Song HJ, Lee TS, Jeong JH, Min YS, Shin CY, Sohn UD 2005 Hydrogen peroxideinduced extracellular signal-regulated kinase activation in cultured feline ileal smooth muscle cells. J Pharmacol Exp Ther 312:391-398

27. Zhang J, Jin N, Liu Y, Rhoades RA 1998 Hydrogen peroxide stimulates extracellular signal-regulated protein kinases in pulmonary arterial smooth muscle cells. Am J Respir Cell Mol Biol 19:324-332

28. Gauthier R, Harnois C, Drolet JF, Reed JC, Vezina A, Vachon PH 2001 Human intestinal epithelial cell survival: differentiation state-specific control mechanisms. Am J Physiol Cell Physiol 280:C1540-1554

29. Wang Q, Wang X, Hernandez A, Kim S, Evers BM 2001 Inhibition of the phosphatidylinositol 3-kinase pathway contributes to HT29 and Caco-2 intestinal cell differentiation. Gastroenterology 120:1381-1392

30. Wang X, McCullough KD, Franke TF, Holbrook NJ 2000 Epidermal growth factor receptor-dependent Akt activation by oxidative stress enhances cell survival. J Biol Chem 275:14624-14631

31. Gopalakrishna R, Jaken S 2000 Protein kinase C signaling and oxidative stress. Free Radic Biol Med 28:1349-1361

32. Niwa K, Inanami O, Yamamori T, Ohta T, Hamasu T, Karino T, Kuwabara M 2002 Roles of protein kinase $\mathrm{C}$ delta in the accumulation of P53 and the induction of apoptosis in H2O2-treated bovine endothelial cells. Free Radic Res 36:1147-1153

33. Chang Q, Tepperman BL 2003 Effect of selective PKC isoform activation and inhibition on TNF-alpha-induced injury and apoptosis in human intestinal epithelial cells. Br J Pharmacol 140:41-52

34. Wen HC, Huang WC, Ali A, Woodgett JR, Lin WW 2003 Negative regulation of phosphatidylinositol 3-kinase and Akt signalling pathway by PKC. Cell Signal $15: 37-45$

35. Gujdar A, Sipeki S, Bander E, Buday L, Farago A 2004 Protein kinase C modulates negatively the hepatocyte growth factor-induced migration, integrin expression and phosphatidylinositol 3-kinase activation. Cell Signal 16:505-513

36. Li L, Lorenzo PS, Bogi K, Blumberg PM, Yuspa SH 1999 Protein kinase Cdelta targets mitochondria, alters mitochondrial membrane potential, and induces apoptosis in normal and neoplastic keratinocytes when overexpressed by an adenoviral vector. Mol Cell Biol 19:8547-8558

37. Alessi DR, Cohen P 1998 Mechanism of activation and function of protein kinase B. Curr Opin Genet Dev 8:55-62

38. Zhang L, Himi T, Morita I, Murota S 2001 Inhibition of phosphatidylinositol-3 kinase/Akt or mitogen-activated protein kinase signaling sensitizes endothelial cells to TNF-alpha cytotoxicity. Cell Death Differ 8:528-536 